\title{
Utilization Of Family Planning Methods Among Rural Women In Ogun State, Nigeria
}

\author{
Mojisola Oyewole \\ Department of Agricultural Extension and Rural Development, University of Ibadan
}

\begin{abstract}
Family planning implies the spacing and timing of childbirth. However, despite many actions put in place by the government at all levels to sensitize citizens on the need for family planning, most of Nigeria's population still does not practice it as expected. Thus, this study aims to investigate whether family planning methods used among rural women in Ogun State were in accordance to government's advices. For this purpose, a multi-stage sampling technique was used to select 120 respondents, and a structured questionnaire schedule was used for the data collection. Quantitative data was collected and analyzed using descriptive and inferential analysis. We used the retest reliability test to validate the instrument, by distributing the instrument to the respondents who were not included in the study. Therefore, based on our study, we concluded that even though most of the women had high information on family planning methods, but they only utilized the commons one. Hence, the grassroot educative training could be the key to enhance their usage of other methods to ensure secure child-bearing.
\end{abstract}

Keywords: Utilization, Family planning, Contraceptives Rural women

\section{INTRODUCTION}

The women unattained needs, such as self-realization, economic fulfillment, which could be linked to the effectiveness usage of contraceptives, recently, have been recognized; moreover, these unmet needs have been raising in the developing countries, since the effective usage of contraceptives hardly met. (Alkema et al., 2013; Darroch, Singh, and Ashford, 2013). According to Singh and Darroch (2012), over 220 million women are in need of modern contraceptives in the developing world, and the numbers may be on the increase due to the increase in population. Campbell, Sahin-Hodoglugil, and Potts (2006) identified the obstacles and barriers of contraceptives usage, such as: lack of information concerning available methods, health concerns, and surrounding available methods. Further, Casterline, Sathar, and ulHaque (2001) added that the women's perception of contraceptives may be in conflict in relation to their husband interests in terms of fertility perspectives and as a result might be a motivating factor to circumvent pregnancy, rather than the use of contraceptives itself. Our empirical experience showed that poverty has associated impacts for family planning: over $70 \%$ of the Nigerian population are living in poverty, including the ones living in the rural areas. With the economic limitation, poor Nigerian are not only hardly to meet daily dietary requirements, but also difficult to afford contraceptive. As a result, frequent unwanted pregnancies have occurred among women with the ages of below 18 to 35 years (National Policy on Population, 2004).We believe that one key to eradicate poverty in Nigeria is to promote family planning program using contraceptive, and women are the main actresses to realize the project. Because once the women were failing their family planning, and unable to control their unwanted pregnancy, the childbearing would decrease the agricultural productivity, as well as the local 
economic growth. At this point, it would be important to understand the women's attitudes toward family planning itself.

Our grassroot experiences showed us that the rural women in Nigeria, are burdened with poor health in conjunction with poorly spaced pregnancies and subsequently give birth to children closely aged in years. Millions of these women do not have access to contraceptives despite the yearning to reduce birth numbers and to increase the space between childbirth appropriately. The spread for contraceptives among rural women is in an urgency situation. Therefore, our society is in the need for human rights and public health specialists called to educate sexual and reproductive health.

We assessed the utilization of family planning methods among rural women in Ogun State, Nigeria. According to the research of Okeowo \& Olujide (2014) stated that among the rural women population in Ogun state there is high prevalence of inaccurate family planning methods and also noted that family planning is not very popular due to it's association with negative side effects .

We specify our objectives: (i) describe the socio-economic characteristics of the rural women in the study area, (ii) determine the awareness of contraceptive method utilized by rural women in the study area, (iii) determine the knowledge of rural women on family planning methods, (iv) identify rural women's sources of information on family planning methods, (v) assess the utilization of family planning methods among the rural women in the study area, (vi) identify factors militating against the utilization of family planning methods among rural women in the study area. The objectives of the study were adapted from that of Okeowo and Olujide (2014).

To develop our objectives, we want to test the following hypotheses:

Ho1: There is no significant relationship between socio-economic characteristics of rural women and their level of utilization of family planning methods,

Ho2: There is no significant relationship between awareness of contraceptive method utilized by rural women and their level of utilization of family planning methods,

Ho3: There is no significant relationship between knowledge of rural women and their level of utilization of family planning methods,

Ho4: There is no significant relationship between the source of information on family planning methods and their level of utilization of family planning methods,

Ho5: There is no significant relationship between factors mitigating and their level of utilization of family planning methods.

\section{THE CONCEPTUAL FRAMEWORK FOR THE STUDY}

The independent variables of this study are the socio-economic characteristics of respondents, awareness of contraceptives utilize by respondents, knowledge on family planning methods, sources of information on family planning methods, and factors militating against the utilization of family planning methods. The socio-economic characteristics of respondents such as age, sex, marital status, religion, education, household size, and income are expected to influence respondents' sources of information on family planning methods, and this will invariably influence their level of awareness on the utilization of contraceptives, their awareness will either increase or decrease their knowledge on family planning methods used which will, in turn, affects the factors mitigating against the utilization of family planning methods. All the independent variables will influence the dependent variable, which is the utilization of family planning methods. 


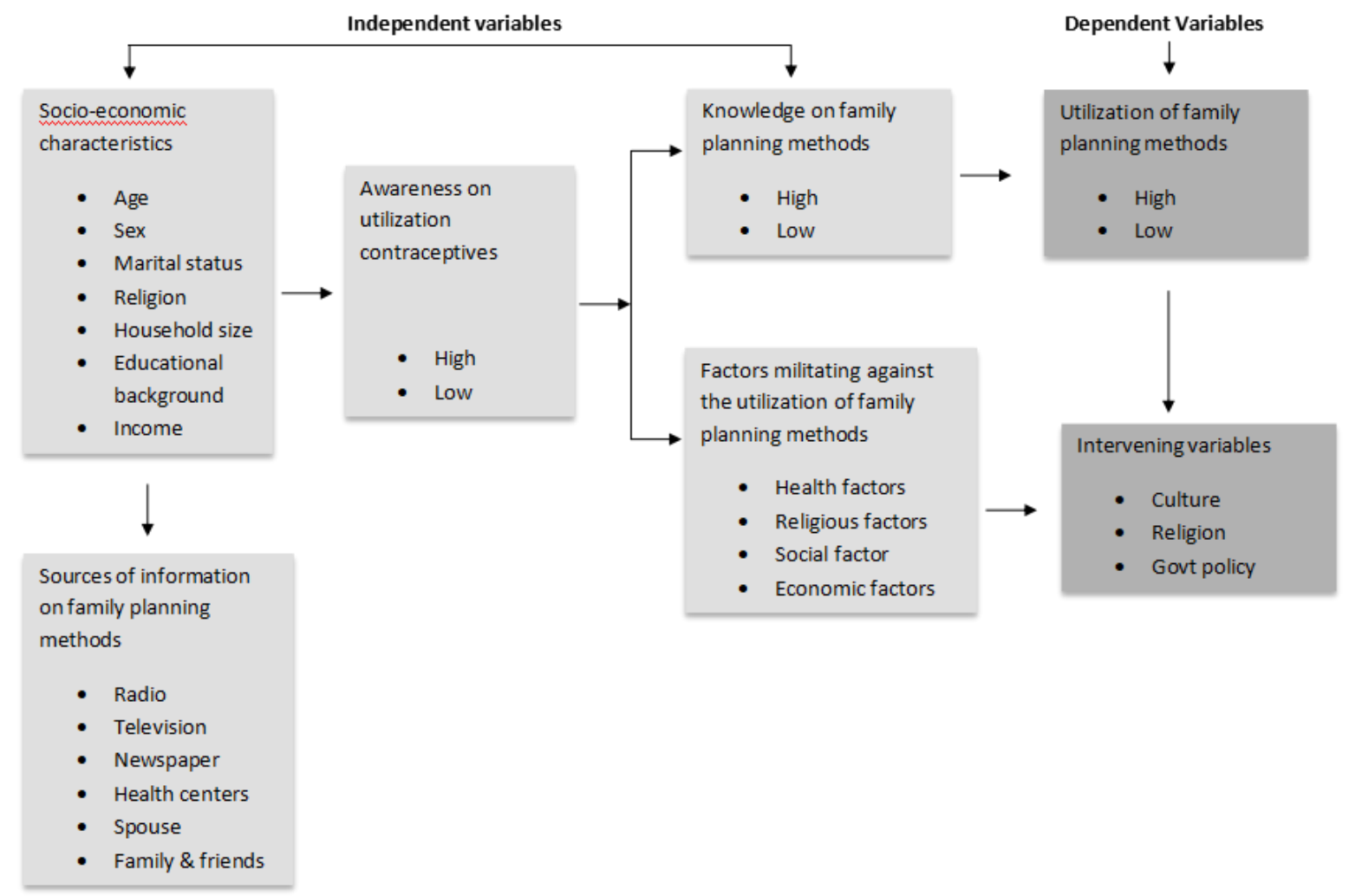

Fig. 1: Conceptual Framework on Utilization of Family Planning Methods among Rural Women in Ogun State, Nigeria,

\section{METHODOLOGY}

Our samples were taken from the Ogun State, Nigeria which population is 3,728,098 people (National Population Commission, 2007). Our study interest were the women between $18-50$ years, and to obtain our measures on them, we use a multi-stage random sampling. The first stage involved the selection of the four zones of OGADEP, namely: Abeokuta, Ilaro, Ikenne, and Ijebu-Ode zones. Stage two will involve the selection of one local government each from the four zones making four local government areas. Stage three involved randomly selecting two villages each from the four local government areas, which gave a total of 8 villages. The last stage involved using a simple random technique to select 120 respondents from 1,203 registered women in the villages selected, therefore making a sample size of 120 respondents.

The questionnaire was structured into six sections on the basis of the specific objectives as follows: Section A was designed to collect information on the socio-economic characteristics of the respondents, section B was designed to elicit information on awareness of contraceptive method utilized by rural women, section $\mathrm{C}$ was targeted data regarding knowledge of rural women on family planning methods, section D collected data on rural women's sources of information on family planning methods, section $\mathrm{E}$ elicit information on the factors militating against the respondents' utilization of family planning methods section $\mathrm{F}$ was designed to collect information on utilization of family planning methods among the rural women. The questionnaire was approved by the department of agricultural extension and rural development research committee- 
We use descriptive statistics such as mean, percentages, frequencies, and inferential statistics such as Chi-square, Product Pearson Moment Correlation (PPMC) to analyze the data for the study.

\section{RESULTS AND DISCUSSION}

Socio-economic characteristics of the respondents

Table 1 shows that $44.2 \%$ of the rural women were between 29 and 38 years, 30.8\% were between 19 and 28, 18.3\% were between 39 and 48 years while a few (6.7\%) of them were between 49 and 58 years. With the average age of 33 years \pm 10 months, it implies that most of the rural women are still young and still in their reproductive age, and hence could influences their utilization of family planning methods to control childbirth. This in line with the findings of Okeowo (2014), who finds out that those rural women who were within the child-bearing age and economically active population were 40 years and less.

On religion, the result shows that $45.0 \%$ of the rural women were Muslims, 48.3 were Christians, while a smaller percentage $(6.7 \%)$ were practicing traditional religion. This shows that more Muslim women constituted the respondents for the study.

On education, the result shows that more than half (57.5\%) of the rural women had secondary education, $24.2 \%$ had tertiary education. Also, $14.2 \%$ had primary education, while $4.2 \%$ of them had no formal education. This implies that most of the rural women had one form of education or the other, which might ease them to process information towards the usefulness of using family planning methods. This in accordance with the findings of Asiabaka (2000) that revealed educational level as a very important determinant in the adoption of innovation and being literate will enable the women to obtain useful information on family planning from various sources but negate the findings of Taiwo (2012) who observed that most of the women in rural communities of Ibadan had only primary education and more women had no formal education compared to those who had secondary and tertiary education.

On marital status, the result shows that the majority $(77.5 \%)$ of the rural women were married, $15.8 \%$ were single, $5.8 \%$ divorced, and $0.8 \%$ of them were a widow. This shows that more married women who were still involved in child-bearing were sampled for the study.

On primary occupation, the result shows that half $(50.0 \%)$ of the rural women were traders, $20.8 \%$ were civil servants, $14.2 \%$ were students, while $7.5 \%$ were farmers and artisans, respectively. This shows that most rural women were more involved in trading as their source of livelihood.

On household size, the result shows that $39.1 \%$ of the respondent had between 5 and 6 persons in their households, 35.8\% had between 3 and 4 persons, $15.8 \%$ had between 7 and 9 persons, while $9.2 \%$ had between 1 and 2 persons in their households. The mean household size of $5 \pm 2$ implies that most of the households had larger households. This means that most of the respondents might not have been using any of the family planning methods. This condition might implies that some respondents are not using the various types of family planning methods or that they are not aware of it.

On income, result shows that $42.5 \%$ of the rural women earned between 35,001 and 60,000 monthly, 39.2\% earned between 10,000 and 35,000 monthly, 9.2\% earned between 60,001 and 85,000 monthly, 7.5\% earned between 85,001 and 110,000 while $1.7 \%$ of them earned Above 110,000. The mean monthly income of $46,791 \pm 25,000$ implies that most of the rural women earned much monthly, and this supposed make any family planning methods affordable.

On member of social association, the result shows that $66.7 \%$ of the rural women were a member of the social association, while $33.3 \%$ of them did not belong to any social association. This shows that most of the rural women had enough time to attend to their social responsibilities. 
International Journal of Management, Entrepreneurship, Social Science and Humanities (IJMESH), Vol. 3 (2), 1-13 Utilization Of Family Planning Methods Among Rural Women In Ogun State, Nigeria

Mojisola Oyewole

Table 1: Distribution of socio characteristics of the respondents(n=120)

\begin{tabular}{|c|c|c|c|c|}
\hline Variables & Frequency & Percentage & Mean & SD \\
\hline Age & & & 33 & 10 \\
\hline $19-28$ & 37 & 30.8 & & \\
\hline $29-38$ & 53 & 44.2 & & \\
\hline $39-48$ & 22 & 18.3 & & \\
\hline $49-58$ & 8 & 6.7 & & \\
\hline \multicolumn{5}{|l|}{ Religion } \\
\hline Christianity & 58 & 48.3 & & \\
\hline Islam & 54 & 45.0 & & \\
\hline Traditional & 8 & 6.7 & & \\
\hline \multicolumn{5}{|l|}{ Education } \\
\hline No formal education & 5 & 4.2 & & \\
\hline Primary education & 17 & 14.2 & & \\
\hline Secondary education & 69 & 57.5 & & \\
\hline Tertiary education & 29 & 24.2 & & \\
\hline \multicolumn{5}{|l|}{ Marital status } \\
\hline Single & 19 & 15.8 & & \\
\hline Married & 93 & 77.5 & & \\
\hline Divorced & 7 & 5.8 & & \\
\hline Widow & 1 & 0.8 & & \\
\hline \multicolumn{5}{|l|}{ Primary occupation } \\
\hline Farming & 9 & 7.5 & & \\
\hline Trading & 60 & 50.0 & & \\
\hline Civil servant & 25 & 20.8 & & \\
\hline Students & 17 & 14.2 & & \\
\hline Artisans & 9 & 7.5 & & \\
\hline Household size & & & 5 & 2 \\
\hline $1-2$ & 11 & 9.2 & & \\
\hline $3-4$ & 43 & 35.8 & & \\
\hline $5-6$ & 47 & 39.1 & & \\
\hline $7-9$ & 19 & 15.8 & & \\
\hline Income & & & 46,791 & 25,000 \\
\hline $10,000-35,000$ & 47 & 39.2 & & \\
\hline $35,001-60,000$ & 51 & 42.5 & & \\
\hline $60,001-85,000$ & 11 & 9.2 & & \\
\hline $85,001-110,000$ & 9 & 7.5 & & \\
\hline Above 110,000 & 2 & 1.7 & & \\
\hline \multicolumn{5}{|c|}{ Member of social association } \\
\hline Yes & 80 & 66.7 & & \\
\hline No & 40 & 33.3 & & \\
\hline
\end{tabular}

Source: Field survey, 2019 
Awareness of contraceptive method utilized by rural women

Table 2 shows that the majority (60.8\%) of the respondents had low awareness of contraceptive methods, while $39.2 \%$ had high awareness. This result indicates a poor level of awareness of rural women on family planning methods. This is in line with the findings of Adetona (2008), who confirmed that the use of contraception had not been well consolidated in Nigeria, most especially in the core areas of the country.

Table 2: Awareness of contraceptive method utilized by rural women(n=120)

\begin{tabular}{lcccccc}
\hline \multicolumn{1}{c}{ Awareness level } & Frequency & Percentage & Minimum & Maximum & Mean & SD \\
\hline Low $(0-4.0)$ & 73 & 60.8 & 0 & 14 & 4.1 & 2.4 \\
High $(4.1-14)$ & 47 & 39.2 & & & & \\
Total & 120 & 100.0 & & & & \\
\hline
\end{tabular}

Source: Field survey, 2019

Respondents' knowledge of family planning methods

Table 3 shows that more than half (56.7\%) of the respondents had high knowledge of family planning methods, while $43.3 \%$ of them had low knowledge. This result shows that though the respondents had low awareness, they possessed high knowledge of the family planning type they utilized.

Table 3: Respondents knowledge of family planning methods

\begin{tabular}{lcccccc}
\hline Knowledge level & Frequency & Percentage & Minimum & Maximum & Mean & SD \\
\hline Low (20-28.5) & 52 & 43.3 & 20 & 39 & 28.6 & 5.0 \\
High (28.6-39) & 68 & 56.7 & & & & \\
Total & 120 & 100.0 & & & & \\
\hline
\end{tabular}

Source: Field survey, 2019

Respondents' sources of information on family planning methods

Table 4 reveals that most of the respondents' sourced information on family planning through television with the highest mean of (1.94). This is followed by radio with a mean of (1.92) and health centers with a mean of (1.84). This implies that television, radio, and health centers were the prominent source most of the rural women sourced information on family planning. This could be because most households had television, radio in their I households, and attend health centers before and after childbirth. Also, most of the respondents' lease sources for information on family planning through churches and mosques with the lowest mean of (0.19) in the study area.

Table 4: Respondents' sources of information on family planning methods ( $\mathrm{n}=120$ )

\begin{tabular}{lccccc}
\hline Sources of information & Always & Occasional & Never & Mean & Rank \\
\hline Radio & $111(92.5)$ & $9(7.5)$ & $0(0.0)$ & 1.92 & $2^{\text {nd }}$ \\
Television & $113(94.2)$ & $7(5.8)$ & $0(0.0)$ & 1.94 & $1^{\text {st }}$ \\
Newspaper/magazines & $38(31.7)$ & $60(50.0)$ & $22(18.3)$ & 1.13 & $4^{\text {th }}$ \\
Health centers & $103(85.8)$ & $15(12.5)$ & $2(1.7)$ & 1.84 & $3^{\text {rd }}$ \\
Spouses & $15(12.5)$ & $59(49.2)$ & $46(38.3)$ & 0.74 & $6^{\text {th }}$ \\
Family and friends & $5(4.2)$ & $52(43.3)$ & $63(52.5)$ & 0.51 & $7^{\text {th }}$ \\
Market places & $4(3.3)$ & $25(20.8)$ & $91(75.8)$ & 0.27 & $9^{\text {th }}$ \\
Churches/mosques & $2(1.7)$ & $19(15.8)$ & $99(82.5)$ & 0.19 & $10^{\text {th }}$ \\
Internets & $7(5.8)$ & $28(23.3)$ & $85(70.8)$ & 0.35 & $8^{\text {th }}$ \\
\hline
\end{tabular}




\begin{tabular}{llllll}
\hline Mobile phones & $19(15.8)$ & $62(51.7)$ & $39(32.5)$ & 0.83 & $5^{\text {th }}$ \\
\hline
\end{tabular}

Source: Field survey, 2019

Factors militating against the utilization of family planning methods among rural women

Table 5 reveals that the increase in body weight experienced by the respondents with the highest mean of (1.55) was the health factors militating against the utilization of family planning methods by rural women. Also, most of the respondents were faced with a religious factor that promotes promiscuity, means that the religion discourages contraceptives in order to have many children, which has the highest mean of (1.73). In addition, a means of controlling population with highest mean of (1.81) were the social factors militating against the utilization of family planning, since the usage of contraceptives will reduce the family labor size with highest mean of (1.35), last, it was the economic factor militating against the utilization of family planning by the rural women. This is similar to the findings of Omo-Agboja et al. (2009) that religion, fear of contraceptive side effects, and infertility in later life as factors influencing the use of family planning measures

Table 5: Factors militating against the utilization of family planning methods among rural women( $\mathrm{n}=120)$

\begin{tabular}{|c|c|c|c|c|c|}
\hline Factors & $\begin{array}{c}\text { Very } \\
\text { important }\end{array}$ & $\begin{array}{c}\text { Moderately } \\
\text { important }\end{array}$ & $\begin{array}{l}\text { Not a } \\
\text { factor }\end{array}$ & Mean & Rank \\
\hline \multicolumn{6}{|l|}{ Health factors } \\
\hline Causes illness like cancer & $8(6.7)$ & $0(0.0)$ & $112(93.3)$ & 0.13 & $6^{\text {th }}$ \\
\hline $\begin{array}{l}\text { Contraceptives make blood } \\
\text { pressure to go up }\end{array}$ & $80(66.7)$ & $5(4.2)$ & $35(29.2)$ & 1.37 & $2^{\text {nd }}$ \\
\hline $\begin{array}{l}\text { An increase in weight is } \\
\text { experienced }\end{array}$ & $87(72.5)$ & $12(10.0)$ & $21(17.5)$ & 1.55 & $1^{\text {st }}$ \\
\hline $\begin{array}{l}\text { Contraceptives make one } \\
\text { sickly and weak }\end{array}$ & $33(27.5)$ & $27(22.5)$ & $60(50.0)$ & 0.77 & $3^{\text {rd }}$ \\
\hline It causes hypertension & $7(5.8)$ & $29(24.2)$ & $84(70.0)$ & 0.35 & $5^{\text {th }}$ \\
\hline $\begin{array}{l}\text { Causes urinary infection } \\
\text { Religious factors }\end{array}$ & $20(16.7)$ & $42(35.0)$ & $58(48.3)$ & 0.68 & $4^{\text {th }}$ \\
\hline $\begin{array}{l}\text { It is against my religious } \\
\text { belief }\end{array}$ & $37(30.8)$ & 32 (26.7) & $51(42.5)$ & 0.88 & $3^{\text {rd }}$ \\
\hline $\begin{array}{l}\text { Family planning is believed to } \\
\text { promote promiscuity }\end{array}$ & $102(85.0)$ & $4(3.3)$ & $14(11.7)$ & 1.73 & $1^{\text {st }}$ \\
\hline $\begin{array}{l}\text { Family planning is used to } \\
\text { control family planning and is } \\
\text { against my religious belief } \\
\text { Social factors }\end{array}$ & $76(63.3)$ & $9(7.5)$ & $35(29.2)$ & 1.34 & $2^{\text {nd }}$ \\
\hline $\begin{array}{l}\text { A means of controlling the } \\
\text { population }\end{array}$ & $107(89.2)$ & $4(3.3)$ & $9(7.5)$ & 1.81 & $1^{\text {st }}$ \\
\hline $\begin{array}{l}\text { The use of family planning is } \\
\text { against the norms and culture } \\
\text { of my village }\end{array}$ & $58(48.3)$ & $13(10.8)$ & $49(40.8)$ & 1.07 & $3^{\text {rd }}$ \\
\hline $\begin{array}{l}\text { Family planning is not } \\
\text { accepted in my marital }\end{array}$ & $69(57.5)$ & $9(7.5)$ & $42(35.0)$ & 1.22 & $2^{\text {nd }}$ \\
\hline
\end{tabular}




\section{settings}

Economic factors

Family planning is costly to do Contraceptives are not easily

$63(52.5)$

$52(43.3)$

$24(20.0)$

$16(13.3)$

$33(27.5)$

$52(43.3)$

$1.25 \quad 2^{\text {nd }}$

accessible in my locality

Contraceptives reduce family

$75(62.5)$

$13(10.8)$

$32(26.7)$

1.35

$1^{\text {st }}$

Source: Field survey, 2019

Utilization of family planning methods among rural women

Table 6a reveals that most of the respondents utilized the Norplant implant with the highest mean of (1.35). This is followed by the use of pills with a mean of (1.18) and use of the injectable method with a mean of (1.15). This shows that most of the respondents utilized the family planning method types they were aware of, as presented in table $2 \mathrm{a}$. However, abstinence with a mean of $(0.08)$ and Coitus-interrupts (withdrawal) with a mean of (0.03) were the least family planning methods utilized by rural women.

Table 6a: Utilization of family planning methods among rural women

\begin{tabular}{lccccc}
\hline Family planning methods & Always & Occasional & $\begin{array}{c}\text { Do not } \\
\text { utilize }\end{array}$ & Mean & Rank \\
\hline Waistband & $19(15.8)$ & $7(5.8)$ & $94(78.3)$ & 0.37 & $7^{\text {th }}$ \\
Armband & $8(6.7)$ & $4(3.3)$ & $108(90.0)$ & 0.16 & $13^{\text {th }}$ \\
Pendant & $1(0.8)$ & $9(7.5)$ & $110(91.7)$ & 0.09 & $15^{\text {th }}$ \\
Prolonged breastfeeding & $34(28.2)$ & $8(6.7)$ & $78(65.0)$ & 0.63 & $5^{\text {th }}$ \\
Scarification & $8(6.7)$ & $8(6.7)$ & $104(86.7)$ & 0.20 & $10^{\text {th }}$ \\
Pills & $63(52.5)$ & $16(13.3)$ & $41(34.2)$ & 1.18 & $2^{\text {td }}$ \\
Intra uterine device (IUD) & $2(1.7)$ & $18(15.0)$ & $100(83.3)$ & 0.18 & $11^{\text {th }}$ \\
Diaphragm & $14(11.7)$ & $20(16.7)$ & $86(71.7)$ & 0.40 & $6^{\text {th }}$ \\
Condom & $60(50.0)$ & $15(12.5)$ & $45(37.5)$ & 1.12 & $4^{\text {th }}$ \\
Norplant implant & $76(63.3)$ & $10(8.3)$ & $34(28.3)$ & 1.35 & $1^{\text {st }}$ \\
Tubal legation & $4(3.3)$ & $23(19.2)$ & $93(77.5)$ & 0.25 & $8^{\text {th }}$ \\
Vasectomy & $6(5.0)$ & $17(14.2)$ & $97(80.8)$ & 0.24 & $9^{\text {th }}$ \\
Injectable & $61(50.8)$ & $16(13.3)$ & $43(35.8)$ & 1.15 & $3^{\text {rd }}$ \\
Spermicidal & $7(5.8)$ & $8(6.7)$ & $105(87.5)$ & 0.18 & $11^{\text {th }}$ \\
Safe periods (rhythm) & $3(2.5)$ & $8(6.7)$ & $109(90.8)$ & 0.11 & $14^{\text {th }}$ \\
Abstinence & $1(0.8)$ & $8(6.7)$ & $111(92.5)$ & 0.08 & $16^{\text {th }}$ \\
Coitus-interrupts & $1(0.8)$ & $2(1.7)$ & $117(97.5)$ & 0.03 & $17^{\text {th }}$ \\
(withdrawal) & & & & & \\
\hline
\end{tabular}

Source: Field survey, 2019

Categorization of the utilization of family planning methods among rural women

Table $6 \mathrm{~b}$ reveals that the average proportion (50.8\%) of the rural women had high utilization of family planning methods used by rural women, while $49.2 \%$ of them had low utilization. This could be because the methods mostly utilized by the respondents were cheap to purchase, and this could make them utilize them regularly. The result obtained in this study corroborated those of Oyewoga and 
Odeyemi (2012) when they reported in their study that only $56 \%$ of those who are sexually active had ever used contraceptives, while $44 \%$ did not.

Table 6b: Categorization of the utilization of family planning methods among rural women $(\mathrm{n}=120)$

\begin{tabular}{ccccccc}
\hline Utilization level & Frequency & Percentage & Minimum & Maximum & Mean & SD \\
\hline Low $(0-7.6)$ & 59 & 49.2 & 0 & 25 & 7.7 & 4.8 \\
High $(7.7-25)$ & 61 & 50.8 & & & & \\
Total & 120 & 100.0 & & & & \\
\hline
\end{tabular}

Source: Field survey, 2019

Test of hypotheses

1. Hypothesis one

There is no significant relationship between the socio-economic characteristics of rural women and their level of utilization of family planning methods.

Chi-square analysis between selected Socio-economic characteristics of the respondents and their level of utilization of family planning methods.

Table 7 shows that there was a significant relationship between a member of social association $(\chi 2=4.268, \mathrm{p}<0.05)$ and the level of utilization of family planning methods. Thus, the null hypothesis is rejected. This implies that being a member of a social association had an influence on the utilization of family planning methods. This could be that engaging in social association could reduce the time most rural women would have for child-bearing. Also, the result further reveals that there was no significant relationship between religion $(\chi 2=0.610, \mathrm{p}>0.05)$, education $(\chi 2=1.921, \mathrm{p}>0.05)$, marital status $(\chi 2=6.650, p>0.05)$, primary occupation $(\chi 2=12.257, p>0.05)$ and level of utilization of family planning methods. Thus, the null is accepted. This implies that religion, education, marital status, and primary occupation of rural women do not have any influence on their utilization of family planning methods.

Table 7: Result of chi-square analysis between selected socio-economic characteristics of the respondents and their level of utilization of family planning methods.

\begin{tabular}{lcccc}
\hline Variables & $\chi^{2}$ & Df & P-value & Decision \\
\hline Religion & 0.610 & 2 & 0.737 & NS \\
Education & 1.921 & 3 & 0.589 & NS \\
Marital status & 6.650 & 3 & 0.084 & NS \\
Primary occupation & 12.257 & 6 & 0.056 & NS \\
Member of social association & 4.268 & 1 & 0.039 & S \\
\hline
\end{tabular}

Source: Field survey, 2019

Pearson correlation analysis between selected Socio-economic characteristics of the respondents and the level of utilization of family planning methods.

Further using Pearson correlation, the result on table 8 shows that there was no significant relationship between age $(r=0.008, p>0.05)$, household size ( $r=0.134, p>0.05)$, monthly income ( $r=-$ $0.106, p>0.05$ ), and level of utilization of family planning methods. Thus, the null hypothesis is accepted. This implies that the age, household size, and monthly income of rural women do not have any influence on their level of utilization of family planning methods. 
Table 8: Result of Pearson correlation analysis between selected socio-economic characteristics of the respondents and the level of utilization of family planning methods. $(\mathrm{n}=120)$

\begin{tabular}{lccc}
\hline Variable & r value & p-value & decision \\
\hline Age & 0.008 & 0.934 & NS \\
Household size & 0.134 & 0.144 & NS \\
Monthly income & -0.106 & 0.249 & NS \\
\hline
\end{tabular}

Source: Field survey, 2019

\section{Hypothesis two}

There is no significant relationship between awareness of contraceptive methods utilized by rural women and their level of utilization of family planning methods.

Table 9 shows that there was a significant relationship between awareness of contraceptives utilize by rural women $(r=0.761, p<0.05)$ and their level of utilization of family planning methods. Thus, the null hypothesis is rejected. This implies that the more the rural women are aware of the contraceptive method, the more they tend to utilize them to control their childbirth in the study area.

Table 9: Result of Pearson correlation analysis between awareness on contraceptives utilized and level of utilization of family planning methods.

\begin{tabular}{cccc}
\hline Variable & rvalue & p-value & decision \\
\hline
\end{tabular}

$\begin{array}{llll}\text { Awareness of contraceptives utilized } & 0.761 & 0.001 & \mathrm{~S} \\ \text { and } & & & \\ \text { Utilization of family planning methods } & & \end{array}$

\section{Source: Field survey, 2019}

\section{Hypothesis three}

There is no significant relationship between the knowledge of rural women and their level of utilization of family planning methods.

Table 10 shows that there was a significant relationship between knowledge $(r=0.617, p<0.002)$ and their level of utilization of family planning methods. Thus, the null hypothesis is rejected. This implies that the higher the knowledge of the rural women, the higher the tendency they utilized family planning methods.

Table 10: Result of Pearson correlation analysis between knowledge on the family planning methods and their level of utilization of family planning methods.

\begin{tabular}{lccc}
\hline \multicolumn{1}{c}{ Variable } & r value & p-value & decision \\
\hline $\begin{array}{l}\text { Knowledge of family planning methods } \\
\text { and }\end{array}$ & 0.617 & 0.002 & $\mathrm{~S}$ \\
Utilization of family planning methods & & &
\end{tabular}

Source: Field survey, 2019 


\section{Hypothesis four}

There is no significant relationship between the source of information on family planning methods and their level of utilization of family planning methods. Table 11 shows that there was a significant relationship between the source of information on family planning methods $(\mathrm{r}=-0.119$, $\mathrm{p}<0.05$ ) and their level of utilization of family planning methods. Thus, the null hypothesis is accepted. This implies that the more rural women get information on radio, television, and health centers, which were the major sources of information available to them, the more they tend to know and utilize family planning methods.

Table 11: Result of Pearson correlation analysis between the source of information on family planning methods and their level of utilization of family planning methods.

\begin{tabular}{lccc}
\hline \multicolumn{1}{c}{ Variable } & r value & p-value & decision \\
\hline $\begin{array}{l}\text { Source of information on family planning } \\
\text { methods }\end{array}$ & -0.119 & 0.025 & $\mathrm{~S}$ \\
and & & & \\
Utilization of family planning methods & & & \\
\hline
\end{tabular}

Source: Field survey, 2019

\section{Hypothesis five}

There is no significant relationship between factors militating against the utilization of family planning methods and their level of utilization of family planning methods.

Table 12 shows that there was a significant relationship between factors militating against the utilization of family planning methods $(r=0.201, \mathrm{p}<0.05)$ and their level of utilization of family planning methods. Thus, the null hypothesis is rejected. This implies that factors mitigating the utilization of family planning methods had an influence on their level of utilization. This means that the higher they are faced with mitigating factors against the utilization of family planning methods, the lesser they tend to utilize them.

Table 12: Result of Pearson correlation analysis between factors militating against the utilization of family planning methods and their level of utilization of family planning methods.

\begin{tabular}{lccc}
\hline \multicolumn{1}{c}{ Variable } & r value & p-value & decision \\
\hline $\begin{array}{l}\text { Factors mitigating against the utilization } \\
\text { of family planning methods }\end{array}$ & 0.201 & 0.028 & $\mathrm{~S}$ \\
and & & & \\
$\begin{array}{l}\text { Level of the utilization of family planning } \\
\text { methods }\end{array}$ & & & \\
\end{tabular}

Source: Field survey, 2019

\section{CONCLUSION}

It is concluded that the majority of rural women in the study were young and married adults with secondary education. Most of the rural women were aware of Norplant implant, use of pills, and injectable methods of family planning, though they possess low awareness. The rural women had high 
knowledge of the family planning methods they used. Television, radio, and health centers were the major sources the rural women got information on family planning, but an increase in weight of the rural women tends to limit the use of family planning methods. A larger proportion of the rural women had high utilization of the family planning method they were familiar with to control childbirth in the study area.

Based on our result, we believe that there are Intervening Variables affecting the connection between the Independent Variables and the Dependent Variable. Thus, for the next research, we consider the existence of intervening variables in between independent and dependent variables. Our experience showed that cultural and government policy might be suit as the good candidates, since they have an influence on the utilization of family planning methods.

\section{RECOMMENDATIONS}

Based on the findings from this study, the following recommendations are made;

a. Health officers should do proper sensitization on different family planning methods to the rural women in the study area.

b. Family planning suppliers need to give full disclosure about various contraceptive methods to reduce negative perceptions leading to educated choices in relation to contraceptive choices.

c. The government should come up with policies that would encourage and enhance rural women's utilization of family planning methods should be encouraged in different areas of Ogun State.

d. Proper education and awareness programs of family planning strategies to create the right awareness

e. Government, non-governmental organizations, international organizations, extension workers, and related agencies through health centers and mass media like radio and television should intensify more on campaigns and awareness about the use of family planning and its benefits which can help couples to take good care of children and reduced poverty.

\section{REFERENCES}

Adetona, C. I. A. (2008). Factors influencing women access to family planning.

Agbamu, J.U. (2000). Agricultural research extension linkages systems: an International perspectives Agricultural research and extension network paper No 106a, London: ODI.

Alkema, Leontine, VladimiraKantorova, Clare Menozzi, and Ann Biddlecom. 2013. "National, regional, and global rates and trends in contraceptive prevalence and unmet need for family planning between 1990 and 2015: A systematic and comprehensive analysis," The Lancet 381(9878): 1642-1652.

Asiabaka, C.C. (2000). Agricultural extension. A handbook for development practitioners. Molsystem united service, omoku, Rivers state, 1-2, Pp. 148-152.

Campbell, Martha, NuriyeNalanSahin-Hodoglugil, and Malcolm Potts (2006). "Barriers to fertility regulation: A review of the literature," Studies in Family Planning 37(2): 87-98.

Casterline, John B. andSinding, Steven W. (2000). Unmet need for family planning in developing countries and implications for population policy. Population and Development Review, 26, 691-+.

Casterline, John B., Zeba A. Sathar, and MinhajulHaque.(2001). "Obstacles to contraceptive use in Pakistan: A study in Punjab," Studies in Family Planning 32(2): 95-110.

Darroch, Jacqueline E., Susheela Singh, and Lori S. Ashford.(2013). "Adding it up: The need for and cost of maternal and newborn care-Estimates for 2012." New York: Guttmacher Institute. 
Darroh, J. E, Sedgh, G and ball, H. (2011). Contraceptive Technologies: Responding to Women's Needs. Guttmacher Institute, New York.

National Policy on population for sustainable development (2004, January).

Okeowo, T. A., \& Olujide, M. G. (2014). Attitude, knowledge and utilization of family planning methods among rural women in Ogun State, Nigeria. Agrosearch, 14(1), 39-53.

Omo-Aghoja, L. O., Omo-Aghoja, V.W., Aghoja, C. O., Okonofua, F. E., Aghedo, O., Umueri, C., Otayohwo, R., Feyi-Waboso, P., Onowhakpor, E. A. \&Inikori, K. A. (2009). Factors associated with the knowledge, practice and perceptions of contraception in rural southern Nigeria. Ghana Medical Journal, 43 (3): 115-121.

Oyewoga, Y. andOdeyemi, K. A. (2012) A study on utilisation of family planning services among the women of reproductive age group in Badagry Local Government Area of Lagos State, Nigeria. Retrieved from: https://wfpha.confex.com/wfpha/2012/webprogra m/Paper9997.html.

Taiwo, P. A. J. (2012) Attitude of women towards family planning in selected rural communities of Ibadan. African Journal for the Psychological Study of Social Issues, 15 (1). Retrieved from: http://www.ajol.info/index.php/ajpssi/article/view/79089. 